УДК 351:316.346.32053.6

DOI: $10.34132 /$ pard2021.12.07

\title{
МІЖНАРОДНИЙ ТА ВІТЧИЗНЯНИЙ ДОСВІД ДЕРЖАВНОЇ ПОЛІТИКИ ФОРМУВАННЯ АКТИВНОЇ ГРОМАДЯНСЬКОЇ ПОЗИЦЇ̈ МОЛОДІ
}

Полторак Л. Ю., канд. пед. наук, ст. викладач, Чорноморський національний університет імені Петра Могили, м. Миколаїв, Україна.

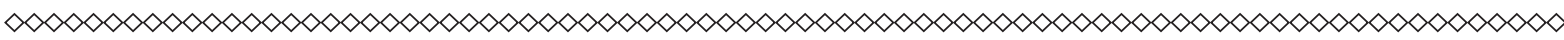

Висвітлено вітчизняний та міжнародний досвід державної молодіжноїполітикиунапрямкуформуванняактивноїгромадянської позиції. Визначено, щцо серед основних напрямків міжнародної молодіжної політики, які є перспективними та важливими для України є сочіальна інклюзія молоді з обмеженими можливостями включення у громадське життя; розширення рівнів участі молоді у громадянському житті від глобального до місцевого; використання можливостей віртуального світу. Прийнята в Украӥні Конщепџія Державної иільової соціальної програми «Молодь України» на 2021-2025 враховує недоліки попередніх років та значно розширює можливості сочіальної інклюзії молоді, яка має менші можливості включення у громадське життя. Однак, вкрай важливим $\epsilon$ забезпечення реалізачії визначеного підходу на всіх рівнях державного та освітнього прочесу. Це ж стосується $і$ другого напрямку - розширення рівнів участі молоді у громадянському житті.

Ключові слова: громадянська позичія, молодь, громадська діяльність, соиіальна інклюзія

Постановка проблеми у загальному вигляді. Децентралізація влади $\epsilon$ важливою складовою розбудови демократичного суспільства, адже фактично повертає громадянам відповідальність 
за прийняття важливих рішень та розвиток громад. Однак, успішний процес децентралізації передбачає наявність активної громадянської позиції населення, яке готове брати на себе відповідальність та приймати участь у розробленні законодавчих положень, у контролі за діяльністю владних структур та у залученні до діяльності громадського сектору. Адже модель демократичного суспільства передбачає двосторонню взаємодію влади та населення. Внутрішня державна політика $\epsilon$ визначальною у формуванні тих норм та цінностей, які домінують у суспільстві, а отже має вагомий вплив на формування світогляду підростаючого покоління та мотивації брати участь у громадянській діяльності. Відтак, формування активної громадянської позиції молоді має бути невід’ємною складовою політики держав, які зорієнтовані на європейські демократичні цінності та соціальний розвиток.

Активну громадянську позицію молоді можна простежити через участь у суспільному житті та замученість населення до діяльності громадських організацій, які дозволяють реалізовувати свої права у різних сферах суспільного життя та відображають ціннісні орієнтації суспільства на замученість до процесів, що відбуваються на місцевому та державному рівнях. В Україні ці показники набагато нижчі за країни європейського союзу, що свідчить про необхідність перегляду вітчизняного та зарубіжного досвіду з метою підвищення державної політики у цьому напрямку.

Аналіз останніх досліджень і публікацій. Питання формування активної громадянської позиції розглядається науковцями у різних площинах: політичній, педагогічній, економічній та психологічній. Серед дослідників, які вивчали це питання у психолого-педагогічному контексті слід визначити В. Астахову, М. Боришевського, В. Демчука, В. Мікуліну, А. Сігову, О. Сухомлинського, М. Шимановського, К. АбульхановуСлавську, Ю. Андреєву, А. Зосімовського, Л. Іванова, Т. Ільїну, Д. Кабалевського, Т. Кузіну, В. Максимову, Т. Мальковську, I. Павлова, В. Петрову, В. Радіонова, О. Щукіну та ін. Вітчизняний та міжнародний досвід державної молодіжної політики відображений працях: Д. Андрєєвої, В. Куйбіди, О. Балакірєвої, О. Лазора, 
В. Барабаша, Я. Немирівського, Є. Бородіна, М. Головатого, В. Головенька, Л. Кривачука, Ю. Криворучка, М. Перепелиці, О. Старинця, С. Толстоухової та ін.

Формулювання цілей статті (постановка задання). Провести порівняння вітчизняного та міжнародного досвіду державної політики формування активної громадянської позиції молоді та визначити перспективні напрямки для України.

Виклад основного матеріалу дослідження. Громадянська активність молоді передбачає наявність сформованої громадянської позиції особистості, яка на думку науковців зводяться до: дієвості, глибокої відповідальності, активної впливовості особистості в суспільстві; усвідомленого сприйняття нею ціннісних проблем; ставлення до суспільних явищ і подій, поведінки, зумовленої цим ставленням; соціально зрілої зацікавленості й готовності працювати для розвитку рідної країни. Громадянська позиція є відтворенням суспільного життя, громадянських прав і безпосередньо впливає на утвердження соціального статусу обистості як громадянина, усвідомлення ним суспільних завдань та соціальну активність. Рівень громадянської позиції багато в чому визначає загальнокультурний рівень розвитку молоді. Критерієм вияву громадянської позиції $є$ здатність і бажання особистості відповідально й активно, на засадах демократизму, громадянського співробітництва, соціальної злагоди, гуманізму й толерантності взаємодіяти 3 соціумом, адекватно співвідносячи й узгоджуючи індивідуальні та загальносуспільні інтереси. У чесному, відповідальному ставленні до самого себе, до реалізації своїх здібностей на суспільну користь виявляється громадянськість особистості [1, с. 329]. Найважливішими ознаками активної громадянської позиції молоді $\epsilon$ сильне, стійке, а не ситуативне, прагнення впливати на соціальні процеси та реальна участь у громадянських справах, яка продиктована прагненням змінити, перетворити або, навпаки, зберегти, зміцнити існуючий соціальний порядок, його форми» [2, с. 93].

Аналіз статистичних даних засвідчує, що молодь в Україні не має сформованої стійкої мотивації до участі у суспільному житті та має вкрай низький рівень сформованості громадянської 
позиції. Так, на основі даних репрезентативного соціологічного дослідження «Молодь України - 2018» було проведено оцінку участі молоді в житті суспільства. Дослідження було спрямоване на вивчення політичної активності молоді, мобільності, залученості до волонтерської діяльності, участі у діяльності інститутів громадянського суспільства, у житті суспільства через Інтернет, відстоювання власної думки. Отримані результати засвідчили, що рівень громадянської активності молоді в Україні значно нижчий, ніж у країнах європейського союзу. Так, за результатами дослідження 56 \% молоді в Україні взагалі не знають, не цікавляться, не виявляють бажання та інтересу до участі у суспільному житті. При цьому 27,3 \% респондентів обізнані про ті чи інші форми участі, знають про різні інструменти участі, але вагаються та не користуються ними. Опитування показало, що лише 16,7 \% молоді тією чи іншої мірою беруть участь у суспільному житті [9].

Водночас, за результатами опитувань громадської думки «Свробарометр» за 2019 рік, більше ніж три четвертих від загальної кількості молоді із країн Свропейського Союзу, беруть участь у різних формах діяльності та долучаються до суспільного життя. Лише 4 \% європейської молоді не залучені до жодної із форм участі молоді. Найбільш поширеними формами участі $є$ участь у виборах (місцевих, національних або європейських) - 72 \% та волонтерській діяльності - 58 \%. При цьому 41 \% молоді бере участь у діяльності студентських або молодіжних організацій, 35 \% молоді відстоює власну думку шляхом участі в різних кампаніях, страйках та вуличних протестах [9].

Представлені результати свідчать про необхідність детальнішого вивчення вітчизняних прогалин у державній молодіжній політиці України, а також використання напрацьованого досвіду європейської спільноти. Підводячи підсумки заходів, реалізованих у цьому напрямку державою за останні п'ять років, у прийнятій Концепції Державної цільової соціальної програми «Молодь України» на 20212025 роки визначено такі основні проблеми української молоді, які перешкоджають формуванню активної громадянської позиції: 
$\checkmark$ низький рівень участі молоді у суспільному житті, в діяльності інститутів громадянського суспільства, у тому числі молодіжних та дитячих громадських організацій, а також органах учнівського та студентського самоврядування, програмах сфери волонтерської діяльності та у процесах ухвалення рішень, що стосуються вирішення питань молоді;

$\checkmark$ низький рівень поінформованості молоді, насамперед молоді з інвалідністю, про свої права, обов'язки та можливості для розвитку власного потенціалу і самореалізації у своїй територіальній громаді, області, в Україні загалом;

$\checkmark$ низька активність молоді в політичному житті країни як на державному, так і на регіональному та місцевому рівні;

$\checkmark \quad$ недостатній рівень мобільності молоді (у межах України та між різними країнами);

$\checkmark$ низький рівень громадянських компетентностей, у тому числі щодо дотримання правових норм, стандартів прав людини, насамперед толерантного ставлення та взаємоповаги один до одного;

$\checkmark$ незначна кількість молоді, які вважають корупцію та непотизм як етично неприйнятні форми розв'язання побутових проблем та життєвих перешкод;

$\checkmark$ підготовка молоді до сімейного життя, відповідального ставлення молоді до планування сім’ї та власного репродуктивного здоров'я;

$\checkmark$ недостатньо сформовані навички здорового способу життя та розуміння важливості комплексної турботи про фізичне та психологічне благополуччя;

$\checkmark$ низький рівень соціалізації, реінтеграції та адаптації молоді, яка проживає у складних життєвих обставинах, вразливих та маргіналізованих груп у суспільстві, насамперед молоді 3 інвалідністю;

$\checkmark$ впровадження Російською Федерацією стратегії мілітаризації освітнього процесу та деструктивного впливу на молодь 3 тимчасово окупованих територій України;

$\checkmark$ недостатній рівень соціально-психологічної адаптації молоді, місцем проживання якої $є$ тимчасово окуповані території, в соціокультурний простір України; 
$\checkmark$ низький рівень компетентностей, необхідних молоді для: свідомого вибору професії та кар'єрного розвитку; провадження підприємницької діяльності; розвитку лідерських якостей [9].

Вивчення європейського досвіду залучення молоді до участі у громадському житті дає можливість визначити перспективні напрямки для України, тому проведемо аналіз основних принципів молодіжної політики в Україні та у країнах Свропейського Союзу.

Особлива увага стратегії залучення молоді до активної громадянської позиції у Свропейських країнах приділяється наступним напрямкам:інклюзія молоді зобмеженими можливостями включення у громадське життя; розширення рівнів участі молоді у громадянському житті від глобального до місцевого; використання можливостей віртуального світу.

Перший напрямок передбачає охоплення всіх молодих людей, незалежно від їх походження або соціального статусу (інклюзія молоді). Для реалізації зазначеного напрямку європейська молодіжна політика зорієнтована на підтримання тих категорій молоді, які за фінансовими або іншими критеріями не мають змоги бути активно залученими у розбудову державних процесів [10].

3 цією метою, наприклад, була запроваджена програма Erasmus+, яка передбачає проведення активних заходів по залученню до активного громадського життя тих категорій молоді, які мають менше можливостей порівняно з однолітками [3]. Особливостями цієї програми є іiі орієнтованість на різноманітність та наявність розроблених практичних рекомендацій.

Так, наприклад, принцип різноманітності програми Erasmus+ передбачає не лише сам факт включеності молоді у активне громадське життя та залучення їх у проекти, але і підвищення рівня знань, обізнаності у важливих соціально-економічних і політичних питаннях та розвиток навичок комунікації. Цей фактор є дуже важливим для залучення молоді у громадське життя, оскільки знання людини, iї навички та життєві цінності відіграють важливу роль у формуванні мотивації особистості реалізовувати свою громадянську активну позицію. 
Наявність розроблених практичних вказівок дозволяє ефективно та швидко реалізовувати молодіжні проекти у різних країнах із дотриманням чітких норм та визначених принципів діяльності проекту. Це дозволяє збільшувати кількість учасників із меншими можливостями 3 кожним роком та підвищувати ефективність програми.

Так, у період з 2007 по 2013 роки у заходах програми «Молодь у дії» взяли участь близько 800000 молодих людей, з яких майже 200000 можна віднести до молоді, яка має обмежені можливості для прояву активної громадянської позиції. Динаміку збільшення числа задіяної молоді із меншими можливостями включення у громадське життя представлена на графіку нижче (рис. 1).

Одним 3 постійних пріоритетів програми «Молодь у дії» була соціальна інклюзія молоді з меншими можливостями. У середньому 47,3 \% підтриманих проектів цієї програми були зорієнтовані на дотримання пріоритету соціальної інклюзії молоді [3, с. 22]. Проте, європейська наукова спільнота відзначає необхідність запровадження більш активних заходів для підвищення рівня включеності молоді 3 меншими можливостями у громадянське життя [3, с. 3].

Україна, на відміну від європейських країн, реалізовувала тривалий час протилежну позицію, орієнтуючись здебільшого на окремі групи молоді. У першу чергу, на обдаровану та творчу молодь, що засвідчує тематика основних напрямків діяльності та заходів, що проводяться на державному рівні Міністерством освіти і науки України, а також Міністерством молоді та спорту [4; 5].

Молодіжна політика, яка впроваджувалася протягом тривалого часу і була зорієнтована, у першу чергу, на обдаровану молодь була заснована на наступних принципах:

- доступності наукових, мистецьких і спортивних закладів для обдарованої молоді незалежно від місця її проживання, етнічного і соціального походження, мовних та інших ознак; індивідуалізації роботи з обдарованою молоддю відповідно до іiі інтересів;

- самореалізації та самоактуалізації; добровільності;

- достатності організаційного, науково-методичного забезпечення; 
- правового захисту інтересів обдарованої молоді [6, с. 33]. Головними завданнями державної політики у роботі 3 обдарованою молоддю можна виділити наступні: громадянське виховання особистості; пошук, розвиток і державна підтримка здібної, обдарованої, талановитої молоді; формування соціально адаптованої особистості та іiї громадського досвіду;

- пропаганда важливості наукових досліджень, мистецьких пошуків молодих людей та захист їхніх авторських прав; задоволення молоді у професійному самовизначенні та творчій самореалізації [6, с. 33].

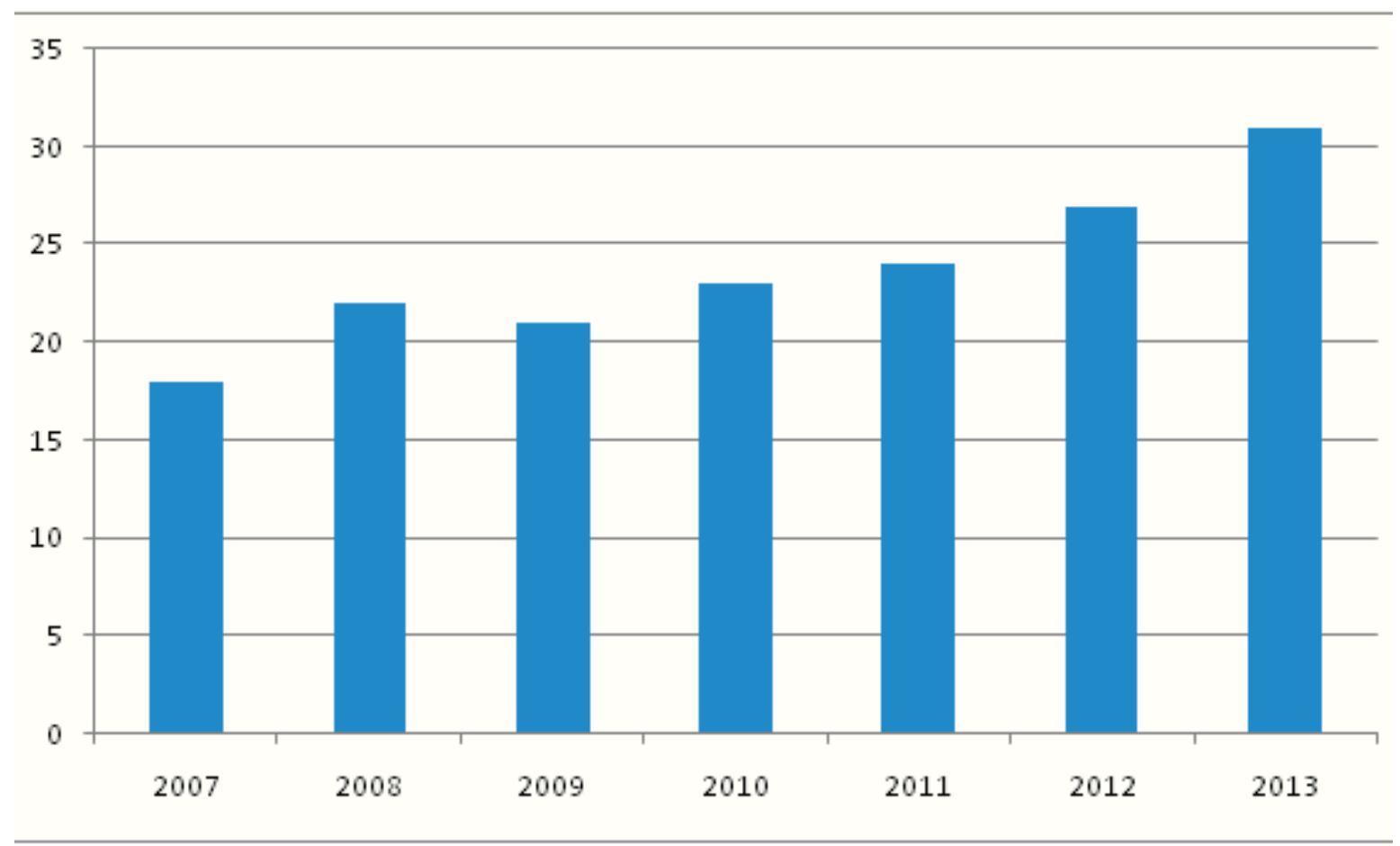

Puc. 1. Відсоток залучення молоді з обмеженими політичними, економічними та іншими можливостями участі у громадянському житті до Програми «Молодь у дії» 2007-2013 pp. [3]

Таким чином, інклюзія в Україні тривалий час була зорієнтована, головним чином, на підвищення можливостей обдарованої та творчої молоді. Інклюзія ж молоді, яка не відноситься до категорії обдарованої, але має менші можливості для включення у громадське життя здебільшого запроваджувалася за рахунок недержавних 
та міжнародних організацій, які дотримуються європейських принципів діяльності, що не давало можливості охопити молодь належним чином. Така державна політика України була недостатньо ефективною, що засвідчили результати соціологічних досліджень за 2019 рік. Творча та обдарована молодь складають незначний відсоток населення, а відтак, поза увагою молодіжної політики залишалася переважна частина молоді. Більш того, обдарована та творча молодь, як правило, вже зорієнтована на самореалізацію та має активну громадянську позицію (має внутрішню мотивацію до такої діяльності). Здебільшого для закріплення у цієї категорії молоді бажання бути активним учасником суспільного та громадського життя достатньо підвищити їх рівень знань та комунікативних навичок, а також забезпечити доступ до інформації про потенціальні можливості та заходи, в яких вони можуть брати участь. Для інших же категорій молоді таких заходів, як бачимо, виявляється недостатньо. Тому надзвичайно актуальним та перспективним напрямком державної політики для України є соціальна інклюзія не лише обдарованої та творчої, але і інших категорій молоді, тобто допомога молоді у наданні більших можливостей для включення у громадське життя.

В контексті зовнішньополітичної складової молодіжної політики України дану проблему слід розглядати виходячи 3 таких двох ключових аспектів діяльності органів державного управління: по-перше, забезпечення молоді широких можливостей для інтеграції в світовий простір, по-друге, створення сприятливих внутрішньополітичних умов для того щоб молодь, поверталася до своєї країни, набувши нових знань, інноваційного досвіду та стимулу до застосування набутого потенціалу під час праці на користь батьківщини [16, с. 496].

Лише у прийнятій Концепції Державної цільової соціальної програми «Молодь України» на 2021-2025 одним із важливих моментів було визначено «впровадження інклюзивного підходу та забезпечення рівних прав, а також доступу до послуг і можливостей, інформації для різних категорій молоді, насамперед для молоді 3 інвалідністю» [9]. Окрема увага у Програмі приділяється наступним 
категоріям молоді: підлітки із сімей, які перебувають у складних життєвих обставинах, діти-сироти, вихованці та випускники інтернатних закладів, молоді сім’ї, які потребують допомоги, молодь $з$ інвалідністю, молодь, що належить до окремих етнічних груп, молодь із різними видами залежності, а також яка відбула покарання у вигляді обмеження волі або позбавлення волі на певний строк. Окремою категорією визначено молодь 3 числа учасників бойових дій та молодь 3 тимчасово окупованих територій України і 3 числа внутрішньо переміщених осіб [9].

Другий напрямок європейської молодіжної політики передбачає розширення рівнів участі молоді у громадянському житті від глобального до місцевого: європейська молодь прагне звернутися до глобальних проблем, зокрема цілей сталого розвитку. У той же час, розширення можливостей молоді розпочинається з локального та місцевого рівнів і залежить від становища та можливостей молоді. Тому, у першу чергу, цей напрямок підтримки молодіжної активності зорієнтований на тісну співпрацю між політичними структурами та молоддю на регіональному та місцевому рівнях, а також на заохочення регіональних та локальних ініціатив молоді [3, c. 3].

В Україні цей напрямок теж не залишається поза увагою. 3 цією метою пріоритетним напрямком підтримки активної громадянської позиції молоді в Україні стала взаємодія та фінансування молодіжних громадських організацій. Так 18 лютого 2016 року було прийнято Державну цільову соціальну програму «Молодь України» на 2016 - 2020 рр., яка передбачала надання фінансової підтримки на реалізацію соціально важливих проектів молодіжних і дитячих громадських організацій. Зокрема, відповідно до звіту Уряду за 2017 р. за підтримки цього міністерства 29 молодіжні та дитячі громадські організації реалізували 41 проект, до яких залучено приблизно 600827 молодих людей [8].

На підтримку проектів і заходів громадських об'єднань i молодіжних ініціатив розроблено i затверджено постановою Кабінету Міністрів України від 18 лютого 2016 р. № 148 Державну цільову соціальну програму «Молодь України» на 2016 - 2020 
pp. Її мета полягає у створенні сприятливих умов для розвитку та самореалізації української молоді, формування іiї громадянської позиції та національно-патріотичної свідомості. Реалізація Державної цільової соціальної програми «Молодь України» передбачає надання фінансової підтримки на реалізацію соціально важливих проектів молодіжних і дитячих громадських організацій. Лідером і координатором забезпечення такої підтримки та взаємодії з інститутами громадянського суспільства $є$ Міністерство молоді та спорту України (Мінмолодьспорту) [22; 23]. Зокрема, відповідно до звіту Уряду за 2017 р. за підтримки цього міністерства 29 молодіжних та дитячих громадських організації реалізували 41 проект, до яких залучено приблизно 600827 молодих людей [8, с. 118].

Однак, варто зауважити, що фінансування молодіжних проектів теж охоплювало, головним чином, ті категорії молоді, які вже мали активну громадянську позицію, вже були членами громадських організацій та прагнули реалізовувати соціальні ініціативи на місцевому рівні. У той же час, дослідження свідчать, що у цілому, кількість молоді, залученої до громадської діяльності залишається вкрай низькою, а кількість молодіжних громадських організацій збільшується повільніше, ніж кількість благодійних, релігійних та профспілкових громадських спільнот [8, с. 118].

Загальнонаціональне дослідження громадської думки населення України, яке було проведене Фондом «Демократичні ініціативи» імені Ілька Кучеріва спільно з Київським міжнародним інститутом соціології з 8 по 20 серпня 2019 року та проводилося в 103 населених пунктах (PSU) у всіх областях України, окрім Автономної Республіки Крим, засвідчило, що у порівнянні із 2013 роком, не зросло членство у громадських організаціях та об'єднаннях: у 2019 році не належали до жодної з організацій, об'єднань чи партій 90\% громадян, у 2013 р. - 85,5\% [7].

Волонтерською діяльністю протягом 2019 року займалися $9 \%$ громадян - фактично стільки ж, скільки у 2012 році (10\%), а це значно менше, ніж торік (18\%), і менше, ніж у 2017 р. (12\%), 2016 p. (14 \%) i 2015 p. (13\%). Найактивніше волонтерством займалися у 
Західному регіоні (14\%), у Центральному і Східному - $9 \%$, а найменш - у Південному (4 \%) [7].

Серед основних причин, через які молодь не приймає участь у діяльності громадських організацій у дослідженні 2019 року було зазначено те, що подібна діяльність взагалі не цікавить респондентів: це зазначили 38,5 \% - істотно більше, ніж у 2018 р. (22 \%) та 2013 р. (23\%). Решта причин - менш суттєві, особливо порівняно 3 попередніми роками, коли більше посилалися на відсутність часу (27\% у 2018 році і 23 \% у 2013 р.). Причому у 2019 році стало помітно менше тих, хто не знає, як можна долучитися до діяльності громадських організацій - $13 \%$, тоді як у 2018 році на це вказували $16 \%$, a y 2013 p. $-21 \%$ [7].

Водночас, 51 \% українців відповіли, що взагалі не збираються брати участь у роботі громадських організацій (рік тому, у 2018 році, таких було значно менше - 36 \%). Спонукати громадян приєднатися до діяльності ГО можуть різні мотиви: якщо організація має репутацію ефективної і такої, що допомагає багатьом людям (15\%), якщо діяльність організації відповідає переконанням людини (13\%), якщо організацію очолює людина, яка викликає довіру та повагу (13 \%), якщо така організація працює на благо України (11\%), якщо ця робота дасть достойний заробіток (12\%), якщо робота в організації дозволить вирішити нагальні проблеми родини (10\%), якщо участь у іiі діяльності дасть нові знання та навички (7 \%), якщо ця робота зараховуватиметься до трудового стажу (6 \%) [7]. Отримані результати свідчать про відсутність сформованої внутрішньої потреби молоді в активній громадській діяльності та про відсутність розуміння важливості їх участі у суспільному житті.

С. Сургова підкреслює, що «молодіжна участь - це надання можливості молодим людям впливати на питання, які стосуються їхнього життя, через участь у прийняття рішень або через особисту діяльність» [19, с. 53]. О. Штирьов зазначає, що саме активна громадянська позиція та залученість населення до діяльності громадських організацій забезпечують населенню можливість здійснення контролю за діяльністю влади та можливість впливу на події у країні. «Завдання громадського контролю полягає у 
тому, щоб не допустити дій контрольованих суб'єктів за межами законності й правопорядку, попередити можливі відхилення від намічених цілей, а також інтересів суспільства та його суб'єктів, а у разі появи цих відхилень усунути їх негативні наслідки» [14, с. 193]. Відірваність молоді від прийняття реальних рішень для українського суспільства матиме прогнозовані негативні наслідки. Як зазначає Д. Сай: «відсутність досвіду прийнятих рішень як і відповідальності за неприйняті ними рішення сприяє формуванню відчуження молоді від процесу прийняття рішень на всіх його рівнях та етапах взагалі» [15, с. 117]. А отже, вкрай важливо сприяти усвідомленню молоддю важливості їх участі у громадському секторі та інформуванню стосовно механізмів здійснення громадського контролю.

Як зазначає Н. Максимовська, соціально активна позиція властива суб〉єкту соціальної творчості і повинна визначати основні параметри включення в суспільство, зокрема - підхід до інших людей, соціальних груп, особиста діяльність та діяльність інших людей, оточуюче соціальне середовище різного рівня організації (громадянська, етнічна, регіональна та глобальна). Для особистості iз сформованою потребою у активній громадській діяльності переважає усвідомлення відповідальності перед суспільством та перспективне бачення своєї діяльності, iї вплив на суспільне життя. Як правило для молоді із сформованої активною громадянською позицією характерні: певні соціальні переживання, бажання нового, честолюбність, готовність до перетворень, соціальна ініціатива, критичне оцінювання соціальної реальності, небайдужість до звичайних громадян та суспільства [13]. Відтак, існує нагальна необхідність вибудовувати державну молодіжну політику не лише через розбудову інклюзивного середовища для молоді, яка має менше можливостей для включення у громадське життя, але і через створення педагогічних умов у навчальних та виховних закладах різних рівнів підготовки, наприклад через запровадження політичної освіти. А. Мороз, розглядаючи політичну освіту як важливу складову політичної соціалізації та становлення активної громадянської позиції молоді, головну іiі мету вбачає в тому, щоб формувати в молоді громадянську компетентність, залучати 
iii до участі в публічній політиці, сприяти розвитку політичної активності, мотивувати до участі в розв'язанні суспільних проблем й розповсюджувати серед молоді головні знання про такі категорії політики як демократія, свобода, справедливість, рівність, чесність, політична участь, прозорість державного управління [16, с. 496]. Відзначаючи важливу роль політичної освіти для виховання патріотизму молоді, Г. Коваль та Д. Боровський особливу увагу звертають на дилемно-контраверсійну модель такої освіти, що орієнтована на розвиток критичності, використання набутих знань для побудови прогностичних моделей майбутнього, залучення до процесу прийняття рішень на різних рівнях. Такий підхід пов’язаний 3 переходом на інноваційний тип навчання, пошук і розроблення нових освітніх технологій [17, с. 231]

Вбачаємо перспективним напрямком використання міжнародного досвіду у цій площині через залучення населення до активного громадського життя на різних рівнях (локальному, місцевому, регіональному, державному тощо). Проте, така діяльність має розпочинатися не з моменту входження у вікову категорію «молодь», а з дошкільних навчальних закладів. Більш того, варто звернути увагу і на діяльність громадських організацій, яка сама по собі може стимулювати молоді до активної участі та сприяти підвищенню інтересу молоді до членства у громадських організаціях. Як зазначає М. Мєфодєва, громадські організації повинні стати взірцями для наслідування молоді та показати молоді свій інтерес та турботу про вдосконалення суспільства $[18$, с. 86]. На рівні громади, відбувається комплексна взаємодія індивіда та різних інституцій. Дослідження Престбі, Вандерсмана, Флоріна, Річа та Чавіса з'ясували, що особи, які були найбільш залучені в активностях громади зазначили про суттєві переваги участі (порівнянно з менш залученими особами) і що вони отримали: нові навички та інформацію, змогли допомогти іншим, збільшили соціальні контакти та виконали зобов'язання [20, с. 74].

Третім важливим напрямком міжнародної молодіжної політики є використання віртуального світу. Оскільки цифрові технології зробили революцію в житті молодих людей і відкрили багато 
нових можливостей у спілкуванні та участі у суспільних процесах, політики повинні враховувати як можливості, так і проблеми, які можуть виникати при використанні потенціалу соціальних медіа. Тому провідне місце молодіжної політики європейських країн займає формування у молоді цифрових навичок, медіа грамотність та розвиток критичного мислення [3, с. 3].

Швеція $є$ однією із тих країн Свропейського Союзу, яка має вагомі напрацювання у цьому напрямку. Запровадження обов'язкової медіаосвіти у Швеції розпочалося ще із 1980 р. та охоплюють усі освітні рівні. Відповідальними за державну політику у цьому напрямку є Шведська національна агенція з освіти та Міністерство освіти Швеції. Зокрема, у навчальних планах, що містять обов'язкові для виконання на всіх рівнях освітньої системи положення зазначено наступне: «Всім студентам повинна бути надана можливість розвинути свої навички використання цифрових технологій. Їм також повинна бути надана можливість розробити критичний і відповідальний підхід до цифрових технологій, щоб мати можливість бачити можливості і розуміти ризики, а також мати можливість оцінювати інформацію» [12]. Такі ж положення зафіксовано у навчальних планах молодшої школи. У березні 2017 p. Уряд Швеції оголосив загальнонаціональну реформу навчальних програм з метою підвищення якості інформування учнів початкових i середніх шкіл, а також закріплення у них навичок та умінь розпізнавати фальшиві новини. Навчальну програму було офіційно запроваджено у дію в липні 2018 р. Шведська рада із засобів масової інформації зобов'язала шведські ЗМІактивно долучитися до виконання цієї програми, а також забезпечує методичний супровід викладачів різних рівнів навчання [12].

Події 2014 року в Україні та інформаційна агресія Росії у медіа-просторі наочно показали важливість впливу засобів масової інформації та необхідність формування медіа-грамотності серед населення різного віку, у тому числі і молоді. Проведені дослідження показали, що в Україні майже 77\% володіють основами комп'ютерної грамотності на високому рівні (C1 $i$ C2) $i$ більше $22 \%$ - на середньому рівні (B1 і В2). Ситуація з комунікацією та 
взаємодією в циифровому суспільстві серед украӥниів значно гірша лише 29\% мають показники високого рівня [11].

Інформаційно-цифрова компетентність увійшла до десяти ключових компетентностей у межах освітньої реформи в Україні та «передбачає впевнене i водночас критичне застосування інформаційно-комунікаційних технологій для створення, пошуку, оброблення, обміну інформацією на роботі, в публічному просторі, приватному спілкуванні тощо» [11]. Також ідеться про навички з інформаційної та медійної грамотності. Наразі медіаграмотність $є$ складовою курсів «Громадянська освіта» для учнів 10-х класів, «Культура добросусідства» - для учнів 1-4 класів. На виконання Державного стандарту базової загальної середньої освіти розроблено типову освітню програму для учнів 5-9 класів, в якій передбачено впровадження з 2022/2023 навчального року курсу «Культура добросусідства», що містить основи медіаграмотності» [11].

Також Міністерство освіти і науки України у партнерстві 3 IREX (Радою міжнародних досліджень та обмінів), МБФ «Академія української преси», за підтримки Посольств США та Великої Британії реалізує проєкт «Вивчай та розрізняй інфо-медійна грамотність». Основна мета даного проекту — «навчити здобувачів освіти критично сприймати інформацію, протидіяти маніпуляціям, усвідомити цінність високоякісної інформації в контексті шкільної освіти» [11]. Наразі проєкт виконується у всіх обласних центрах, а також у Маріуполі, Краматорську та Сєвєродонецьку. До реалізації проєкту залучені 655 шкіл (655 директорів, 3587 вчителів), 25 ІППО та 21 ЗВО (1225 викладачів і методистів). Діяльність проєкту направлена на розвиток навичок критичного сприйняття інформації та інтеграцію інфо-медійної грамотності в навчальну програму шкіл, ЗВО та ІППО. В межах проєкту розробляються навчальні матеріали для вчителів вибраних предметів (8-10 класи), проводяться тренінги та навчання для установ-учасників проєкту (школи, ІППО, педагогічні 3ВО), впроваджується навчання за підготовленими матеріалами та оновленими навчальними програмами [11]. Така активна державна політика у сфері цифрової та медіа-грамотності 
серед населення мала свої позитивні результати. Дослідження, проведене Київським міжнародним інститутом соціології у 2018 р. показало, що українці вважають необхідним навчання медіаграмотності. Так, на запитання «Чи вважаєте ви, що потрібно запровадити навчання 3 медіаграмотності?» $45 \%$ громадян відповіли, що у школах має бути запроваджено навчальний курс відповідного напрямку, 40 \% опитаних вважають, що такий курс необхідний у вищих навчальних закладах. 27,8 \% зазначили про необхідність запровадження широких просвітницьких кампаній 3 медіаграмотності для дорослих. Лише 12,1 \% вважають, що навчання медіаграмотності не потрібно. Особисто погодилися б узяти участь у навчальному курсі 22 \% опитаних. Найбільше зацікавлені в таких курсах жителі заходу України - серед них 31 \% узяли б участь, не більше $20 \%$ виявили бажання взяти участь в інших регіонах. Серед них переважна більшість (56 \%) віддають перевагу курсам в інтернеті [12].

Висновки. Проведений аналіз дозволив зробити висновки, що серед основних напрямків міжнародної молодіжної політики, які $є$ перспективними та важливими для України є соціальна інклюзія молоді 3 обмеженими можливостями включення у громадське життя; розширення рівнів участі молоді у громадянському житті від глобального до місцевого; використання можливостей віртуального світу. Прийнята в Україні Концепція Державної цільової соціальної програми «Молодь України» на 2021-2025 враховуєнедолікипопередніх років тазначно розширює можливості соціальної інклюзії молоді, яка має менші можливості включення у громадське життя. Однак, вкрай важливим є забезпечення реалізації визначеного підходу на всіх рівнях освітнього процесу. Це ж стосується і другого напрямку - розширення рівнів участі молоді у громадянському житті. Створення умов для включення населення до громадського життя та формування активної громадянської позиції має відбуватися на всіх рівнях, починаючи 3 дошкільних навчальних закладів. Саме такий підхід сприятиме формуванню у молоді усвідомленого ставлення до власної позиції у суспільстві та формуванню внутрішньої мотивації до участі у 
громадському житті. Перспективним для України є продовження запровадженої політики у сфері меда-грамотності на найближчі роки.

\section{Стаття надійшла до редакції: 11.04.21}

\section{INTERNATIONAL AND DOMESTIC EXPERIENCE OF PUBLIC POLICY FORMATION OF AN ACTIVE CIVIL POSITION OF THE YOUNG GENERATION}

Liubov Poltorak, PhD in Pedagogy, Petro Mohyla Black Sea National University, Mykolaiv, Ukraine.

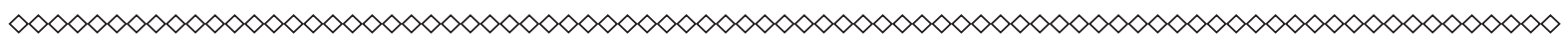

The article highlights Ukrainian and international experience of forming and developing state youth policy in the sphere of active civic engagement. The findings suggest that European countries devote much attention to the following areas: social inclusion of young people with disabilities in public activities; increase in the levels of youth participation in civic life ranging from global to local; use of the possibilities of the virtual world. The study provides a comparative analysis of the effectiveness of measures implemented at the state level and identifies prospects for further development in this area.

Taking into consideration the main areas of international youth policy the evidence from this study indicates that there are several promising and important areas in this domain for Ukraine among which are: social inclusion of young people with disabilities in public life; expansion of the levels of youth participation in civic life from global to local; use of the possibilities of the virtual world.

The Concept of the State Targeted Social Program "Youth of Ukraine" for 2021-2025 adopted in Ukraine takes into account the shortcomings of previous years and significantly expands the opportunities for social inclusion of young people who have fewer opportunities for inclusion in public life. However, it is extremely important to ensure the implementation of a certain approach at all levels of the educational process. The same 
applies to the second direction - expanding the levels of youth participation in civic life. The creation of conditions for the inclusion of the population in civic activities and the formation of an active citizenship should take place at all levels, starting with preschool educational institutions. This approach will help to form in young people a conscious attitude to their own position in society and the formation of an intrinsic motivation to participate in public life. It is promising for Ukraine to continue the introduced policy in the field of media literacy for the coming years.

Key words: civic engagement, youth, public activity, social inclusion, active citizenship.

\section{Received: 11.04.21}

\section{References}

1. Diachenko I.M. (2016). Formuvannia aktyvnoi hromadianskoi pozytsii studentiv: tsinnisni determinanty [Formation of active civic position of students: value determinants]. Retrieved from http://www.irbis-nbuv.gov.ua/cgi-bin/ irbis_nbuv/cgiirbis_64.exe?I21DBN=LINK\&P21DBN=UJRN\&Z21ID $=\& S 21$ $\mathrm{REF}=10 \& \mathrm{~S} 21 \mathrm{CNR}=20 \& \mathrm{~S} 21 \mathrm{STN}=1 \& \mathrm{~S} 21 \mathrm{FMT}=\mathrm{ASP} \_$meta $\& \mathrm{C} 21 \mathrm{COM}=\mathrm{S} \& 2$ S21P03 $=$ FILA $=\& 2 \_S 21 S T R=P f t o \_2016 \_48 \_46$ [in Ukrainian].

2. Romaniv T. (2009). Zasady formuvannia aktyvnoi hromadianskoi pozytsii molodi [Principles of forming an active civil position of youth]. Molodizhna polityka: problemy ta perspektyvy - Youth policy: problems and prospects, (pp. 92-94) [in Ukrainian].

3. Erasmus + Inclusion and Diversity Strategy European Commission Directorate General for Education and Culture. (2014). (n.d.) ec.europa.eu. Retrieved from https://ec.europa.eu/assets/eac/youth/library/reports/inclusiondiversity-strategy_en.pdf [in English]

4. Ofitsiinyi sait Ministerstva molodi ta sportu Ukrainy [Official site of the Ministry of Youth and Sports of Ukraine]. sport.gov.ua. Retrieved from https:// sport.gov.ua/ [in Ukrainian].

5. Ofitsiinyi sait Ministerstva osvity i nauky Ukrainy [Official site of the Ministry of Education and Science of Ukraine]. mon.gov.ua. Retrieved from https://mon.gov.ua/ua [in Ukrainian]. 
6. Obdarovana molod Ukrainy: otsinka suchasnoho stanu ta poshyrennia perspektyvnoho dosvidu roboty z obdarovanoiu moloddiu v rehionakh Ukrainy [Gifted youth of Ukraine: assessment of the current state and dissemination of promising experience of working with gifted youth in the regions of Ukraine]. (2008) [in Ukrainian].

7. Zahalnonatsionalne doslidzhennia hromadskoi dumky [National survey of public opinion]. (n.d.) dif.org.ua. Retrieved from https://dif.org.ua/article/ gromadyanske-suspilstvo-v-ukraini-poglyad-gromadyan [in Ukrainian].

8. Kanavets M. (2018). Suchasnyi stan ta perspektyvy rozvytku vzaiemodii molodizhnykh hromadskykh orhanizatsii z orhanamy publichnoi vlady $\mathrm{i}$ obiednanymy terytorialnymy hromadamy $\mathrm{v}$ umovakh detsentralizatsii [Current state and prospects of development of interaction of public organizations of youth with authorities and the united territorial communities in the conditions of decentralization]. Derzhavne upravlinnia ta mistseve samovriaduvannia - Public administration and local self-government, 3(38). Retrieved from http://www.dridu.dp.ua/vidavnictvo/2018/2018_03(38)/17. pdf [in Ukrainian].

9. Kontseptsiia Derzhavnoi tsilovoi sotsialnoi prohramy «Molod Ukrainy» na 2021-2025 roky [The concept of the State target social program «Youth of Ukraine» for 2021-2025]. (n.d.). zakon.rada.gov.ua. Retrieved from https:// zakon.rada.gov.ua/laws/show/1669-2020-\%D1\%80\#Text

10. Communication from the commission to the Europian Parliament, the Europian Council, the Council, the European economic and social committee and the committee of the regions. (2018). (n.d.). ec.europa.eu. Retrieved from https://ec.europa.eu/youth/sites/default/files/youth_com_269_1_en_act_part1_ v9.pdf [in English].

11. Initsiatyva prezydenta Ukrainy shchodo provedennia urokiv mediahramotnosti v shkolakh [Initiative of the President of Ukraine to hold media literacy lessons at school]. (2011). (n.d.). mon.gov.ua. Retrieved from https://mon.gov.ua/ua/news/mon-pidtrimuye-iniciativu-prezidenta-ukrayinishodo-provedennya-urokiv-mediagramotnosti-v-shkolah [in Ukrainian]

12. Mizhnarodnyi dosvid vprovadzhennia mediahramotnosti dlia okremykh tsilovykh hrup: mozhlyvosti dlia Ukrainy [International experience in introducing media literacy for certain target groups: opportunities for Ukraine]. (n.d.). niss. 
gov.ua. Retrieved from https://niss.gov.ua/doslidzhennya/informaciyni-strategii/ mizhnarodniy-dosvid-vprovadzhennya-mediagramotnosti-dlya [in Ukrainian].

13. Maksymovska N.O. (2019). Social Mission of Students in the Educational Process: The Past and the Present Journal of Educational and Social Research, (Vol 9), 3. Retrieved from https://www.mcser.org/journal/index.php/jesr/article/ view/10484/10113 Doi: 10.2478/jesr-2019-0019 [in English].

14. Shtyrov O. M. (2016). Zarubizhnyi dosvid zdiisnennia hromadskoho kontroliu pid chas nadannia upravlinskykh posluh [Foreign experience of public control in the provision of management services]. Naukovi pratsi Chornomorskoho derzhavnoho universytetu imeni Petra Mohyly kompleksu "Kyievo-Mohylianska akademiia". Seriia : Derzhavne upravlinnia - Scientific works of the Petro Mohyla Black Sea State University of the Kyiv-Mohyla Academy complex. Series: Public Administration, 255, 193-197. Retrieved from http://nbuv.gov.ua/UJRN/Npchdu_2016_267_255_32 [in Ukrainian].

15. Say D.V. Problemy formuvannia hromadianskoi aktyvnosti molodi $\mathrm{z}$ invalidnistiu (2021) [Problems of formation of civic activity of youth with disabilities ]. Olviiskyi forum - 2021 - Olbia Forum - 2021, 116-119 [in Ukrainian].

16. Moroz A. S. (2010). Formuvannia aktyvnoi hromadianskoi pozytsii molodi yak zaporuka uspishnoi intehratsii Ukrainy do svitovoho spivtovarystva [Formation of an active civil position of youth as a guarantee of successful integration of Ukraine into the world community]. Hileia: naukovyi visnyk Gilea: scientific bulletin, 41(11), 490 - 501 [in Ukrainian].

17. Koval H. (2009). Patriotyzm v politychnii kulturi molodi [Patriotism in the political culture of youth] Suchasna ukrainska polityka. Polityky i politolohy pro nei - Modern Ukrainian politics. Politicians and political scientists about it. Київ, Миколаїв : Вид-во «Український центр політичного менеджменту», 16, 227-232 [in Ukrainian].

18. Mefodeva M. (2019). The Students Value Attitude to Healthy Lifestyle // Journal of Educational and Social Research, Vol 9, No 4 Retrieved from https:// www.mcser.org/journal/index.php/jesr/article/view/10533/10162 Doi: 10.2478/ jesr-2019-0056 [in English].

19. Surhova S.Iu. (2020). Studentska molod - rushiina syla ukrainskoho suspilstva [Student youth is the driving force of Ukrainian society]. Mohylianski chytannia - 2020: Dosvid ta tendentsii rozvytku suspilstva v Ukraini - 
Mohyla Reading - 2020: Experience and trends in society in Ukraine, 53-56 [in Ukrainian].

20. Say D.V. (2020). Osoblyvosti nasnazhennia molodi z invalidnistiu u hromadi [Peculiarities of encouraging young people with disabilities in the community] Mohylianski chytannia - 2020: Dosvid ta tendentsii rozvytku suspilstva v Ukraini - Mohyla Reading - 2020: Experience and trends in society in Ukraine, 74-77 [in Ukrainian].

\section{Відомості про авторів / Information about the Authors}

Полторак Любов Юріївна: Чорноморський національний університет ім. Петра Могили: вул. 68 десантників 10, Миколаїв, 54003, Україна.

Liubov Poltorak: Petro Mohyla Black Sea National University: 68 Desantnykiv str. 10, Mykolaiv, 54003, Ukraine.

ORCID.ORG/0000-0002-7733-4506

\section{E-mail: liubovpoltorak@gmail.com}

